\title{
COLLECTIVE BARGAINING, GRIEVANCE ADJUSTMENT, AND THE RIVAL UNION
}

A recent decision by the Court of Appeals for the Second Circuit raises serious problems in the interpretation of the amended National Labor Relations Act, ${ }^{I}$ for it suggests not only that major inroads have been made into the scope of collective bargaining, but also that inter-union rivalry in the employment relationship may now remain a problem even after certification of a collective bargaining representative. Judge Learned Hand, in Douds v. Local r250, has interpreted the amended proviso to Section 9(a) of the Act as obliterating the distinction between "grievances" and "other disputes." This interpretation creates uncertainty as to the rights under the Act of both the certified representative and the individual employee. First, it raises the problem of whether, before the adoption of a collective contract, any subject now lends itself exclusively to the process of collective bargaining. The court's interpretation, moreover, suggests that the certified representative, by providing for the settlement of every kind of dispute in the collective contract, might be able to nullify the right of individual employees to adjust separately any claim with their employer. Finally, in permitting a rival union to represent employees in the adjustment of a grievance, the decision suggests that the rights of both the certified representative and the employer have been seriously diminished. To examine the import which the case may have on future labor relations, it would be well to state briefly the concepts of collective bargaining and grievance adjustment as they have heretofore been known.

The principle of collective bargaining, as expressed in Sections 8(5) and 9(a) of the Wagner Act, requires that employers shall be under a duty to bargain exclusively with a properly designated representative of their employees with respect to "rates of pay, wages, hours of employment, or other general conditions of employment." 3 Once a representative has been elected and certified, it appears that the employer is under an affirmative duty to bargain collectively with respect to almost any problem which the representative may raise, 4

${ }^{x} 49$ Stat. 449 (1935), 29 U.S.C.A. § I5I (Supp. I947); as amended, 6I Stat. I36 (I947), 29 U.S.C.A. \& 15 I (Supp. I949).

$=$ I73 F. $2 d{ }_{7} 64$ (C.A. 2d, I949).

3 Section 8 (d) of the amended Act defines collective bargaining as "the performance of the mutual obligation of the employer and the representative of the employees to meet at reasonable times and confer in good faith with respect to wages, hours, and other terms and conditions of employment." In NLRB v. Sands Mfg. Co., 306 U.S. 332, 342 (I939), it was said that the congressional purpose of the Wagner Act was "to compel employers to bargain collectively with their employees to the end that employment contracts binding on both parties shall be made." See 16 Univ. Chi. L. Rev. 568 (I949), noting Inland Steel Co. v. NLRB, I7o F. $2 d 247$ (C.A. $7_{\text {th }}$ I948).

4 Subjects concerning which employers have been found under a duty to bargain include (I) retirement plans: Inland Steel Co. v. NLRB, 170 F. 2d 247 (C.A. 7th, 1948); (2) merit increases:NLRB v. J. H. Allison \& Co., I65 F. $2 \mathrm{~d} 766$ (C.C.A. 6th, I948); (3) Sunday and holiday provisions: Singer Mfg. Co., 24 N.L.R.B. 444 (I940), enforced as mod. IIg F. 2 d I3I (C.C.A. 7th, 194I); (4) health and welfare plans: Glenn L. Martin Co., I6 L.R.R.M. I6II (I945); 
and, at the same time, is under a negative duty to make no contract with his employees except through that representative. 5

Section 9(a) of the original Act contained a proviso which reserved to individual employees or groups of employees "the right at any time to present grievances to their employer." The National Labor Relations Board interpreted this proviso as reserving only the right to lay grievances before the employer and insisted that adjustments could be made only through negotiation with the bargaining representative. ${ }^{6}$ The courts, however, did not agree with this interpretation. In NLRB v. Union Pacific Stages, ${ }^{7}$ the Court of Appeals for the Ninth Circuit set aside an order of the Board which had found an employer guilty of an unfair labor practice in separately settling a grievance over back pay after the certified union had been called in and was attempting to negotiate an adjustment. The same court later held, in NLRB v. North American Aviation, ${ }^{8}$ that an employer could not be ordered to cease the separate hearing and adjustment of his employees' grievances even though a complete grievance procedure had been established by the existing collective agreement.9 As a result of these interpretations, it was seen that practical differences might result from the selection of the appropriate procedure for settling disputes. It therefore became necessary to draw a meaningful distinction between those demands which had to be bargained exclusively with the certified representative in accordance with Section 8(5) and those demands which, as "grievances" within the meaning of the proviso to Section $9(\mathrm{a})$, could be settled with the aggrieved employee.

(5) union security: National Licorice Co., 7 N.L.R.B. 537 (I938), enforced as mod. 309 U.S. $35^{\circ}$ (I940).

5 Medo Photo Supply Corp. v. NLRB, 32 U.S. 678 (I944); NLRB v. Highland Shoe, Inc., II9 F. 2d 2 I8 (C.C.A. Ist, I94 I); Humble Oil \& Refining Co. v. NLRB, II3 F. 2d 85 (C.C.A. 5 th, I940).

The employer is also denied the right to take unilateral action affecting general conditions of employment once certification has been granted. May Department Stores Co. v. NLRB, 326 U.S. 376 (I945); NLRB v. Sands Mfg. Co., 306 U.S. 332 (I939); General Motors Corp., 59 N.L.R.B. II 43 (I944), enforced General Motors Corp. v. NLRB, I50 F. 2 d 201 (C.C.A. 3 d, 1945$)$.

${ }^{6}$ U.S. Automatic Corporation, 57 N.L.R.B. 124 (1944); Hughes Tool Co., 56 N.L.R.B. 98x (1944), enforced as mod. 147 F. 2 d 69 (C.C.A. 5th, I945); cf. Arundel Corporation, 59 N.L.R.B.505 $\left(x_{944}\right)$. This interpretation was apparently consistent with the congressional intent at the time of the adoption of the Wagner Act. See Hearings before Committee on Labor on H.R. 6288, 74th Cong. Ist Sess., at 2xI (I935) (proviso should "go no further" than to provide individuals with the right to "present" grievances); Hearings before Committee on Education and Labor on S. I958, 74th Cong. Ist Sess., at 321 (1935) (statement that individual grievances must be turned over to majority representative for adjustment); Weyand, Majority Rule in Collective Bargaining, 45 Col. L. Rev. 556, 568-9 (x945).

${ }^{7} 99$ F. $2 d 1_{53}$ (C.C.A. 9 th, 1938 ).

${ }^{8}$ I36 F. 2d 898 (C.C.A. 9th, r943), noted in 44 Col. L. Rev. 97 (I944).

${ }^{9}$ Despite the holding of the North American Aviation case, however, the Board's General Counsel continued to interpret the proviso as reserving only the right of employees to be present at every stage of the grievance procedure while the certified representative was to be permitted to negotiate. I2 L.R.R.M. 224x (1943). 
This problem was squarely presented to the Court of Appeals for the Fifth Circuit in Hughes Tool Co. v. NLRB. ${ }^{10}$ There the court set aside an order by the Board that the employer cease and desist from adjusting grievances with anyone but the certified union, but enforced an order that he notify the union so that it could be present at the grievance adjustment and thus protect its rights under the existing agreement. The opinion carefully distinguished between grievances and matters appropriate to collective bargaining..x Where a grievance involves "only some question of fact or conduct peculiar to the employee, not affecting the unit," the court said that the employer is not obliged to negotiate with the representative. Regardless of whether the particular claim is a grievance, however, if it raises "a question of the meaning of the contract, or present[s] a situation not covered by the contract touching which an agreement ought to be made... it is plain that the representative ought to participate, for bargaining, rather than mere decision on a case according to the contract, is involved." "r2

The Taft-Hartley Act made no changes in the provisions of Section $8(5)$ of the Act, but the proviso to Section 9 (a), reserving the right of individual employees or groups of employees to present grievances, was amended by the addition of the following terms:

... and to have such grievances adjusted, without the intervention of the bargaining representative, as long as the adjustment is not inconsistent with the terms of a collective-bargaining agreement or contract then in effect; Provided further, That the bargaining representative has been given opportunity to be present at such adjustment..3

It will be seen that these words might be read as establishing a grievance procedure not materially different from that suggested by the Fifth Circuit's interpretation of the old Act. ${ }^{{ }_{4}}$ An entirely different interpretation has been

${ }^{10}$ I47 F. 2 d 69 (C.C.A. 5 th, 1945), noted in 44 Mich. L. Rev. 320 (I945).

II "[C]ollective bargaining in respect to rates of pay, wages, hours of employment and other conditions of employment which will fix for the future the rules of employment for everyone in the unit, is distinguished from 'grievances,' which are usually the claims of individuals or small groups that their rights under the collective bargain have not been respected." Hughes Tool Co. v. NLRB, I47 F. $2 d$ 69, 72. (C.C.A. 5th, I945). A similar distinction was drawn by the Supreme Court in Elgin, Joliet \& Eastern Ry. Co. v. Burley, 325 U.S. 7Ir, 723 (1945).

12 Hughes Tool Co. v. NLRB, I47 F. 2d 79, 72 (C.C.A. 5th, I945).

${ }_{3}$ 6I Stat. I $_{43}$ (1947), 29 U.S.C.A. \& I59 (a) (Supp. I949).

${ }^{4}$ Thus the amended proviso, like the Hughes Tool Co. interpretation, might permit separate adjustment of personal claims not covered by an existing contract. Unlike that interpretation, however, the proviso might also permit separate adjustment of such claims even when provided for in an existing agreement so long as the adjustment made is not inconsistent with that agreement. But see Individual Employee Grievances under the Wagner and Taft-Hartley Acts, [1949] Wis. L. Rev. 154. Of three possible interpretations of the proviso's ambiguous language, Professor Cox favors one which would permit separate adjustment but require that the representative later be called in to express his views and carry the grievance to any final adjustment provided for in an existing agreement. Cox, Some Aspects of the Labor Management Relations Act, 1947, 61 Harv. L. Rev. 274, 303 (I948). 
made in Douds v. Local r250, ${ }^{\text {,s }}$ however. In that case the NLRB had certified an AFL union as exclusive bargaining representative for all the employees in the unit, and Local I250 had been enjoined from engaging in, or inducing others to engage in, a strike for the purpose of obtaining recognition as bargaining representative for any of the employees. After certification but before the adoption of a collective contract, Local I250 picketed the employer's establishment in protest against his refusal to deal with it regarding the reinstatement of fiftyone of its members who had been discharged for previous strike activity. ${ }^{16}$ This picketing was found to be in violation of the injunction. In setting aside an order imposing fines for that violation, the court held that Section 8(b) (4) (c), defining unfair union practices, ${ }^{17}$ must be read consistently with the other provisions of the Act. An injunction issued to prevent the violation of that section should not, therefore, be held to include the activities of Local I250 so long as the question of reinstatement of discharged employees was a "grievance" which the employer could have adjusted with the Local. The demand for reinstatement was held to be such a grievance because the amendment to the Section 9(a) proviso had eliminated the old distinction between "grievances" and matters appropriate to collective bargaining. Employees may now separately settle any dispute, continued the court, so long as its adjustment does not conflict with an existing collective agreement. Since no agreement was in effect at the time of the Local's demand for recognition, it was held that the adjustment of a dispute over reinstatement could not be inconsistent with any agreement and could therefore be separately made..$^{18}$

In finding that the old distinction between grievances and other disputes had been eliminated, ${ }^{19}$ Judge Hand interpreted the amendment to the Section 9 (a) proviso as having given to the bargaining representative a "paramount author-

is Note 2 supra.

${ }^{36}$ Local $\mathrm{r} 250$, formerly the certified union, had struck in protest against the Board's ruling that it could not participate in a new election because of the refusal of its officers to file nonCommunist affidavits. The employer offered to take back the discharged employees without loss of seniority, but not until new vacancies were opened.

17 That section prohibits strikes for the purpose of obtaining recognition as representative of the employees in a unit while the certification of another is in effect. It was apparently intended to forbid only those strikes "in which one union is certified by the National Labor Relations Board and another union strikes against the decision of the ... Board." Remarks of Senator Taft, 93 Cong. Rec. 3838 (r947). Injunctions to prevent the violation of Section 8(b) are authorized by Section ro(l) of the Act.

${ }^{18}$ Under the old Act it was an unfair labor practice for an employer to refuse to bargain with the representative with respect to reinstatement. NLRB v. Bachelder, I20 F. 2d 574

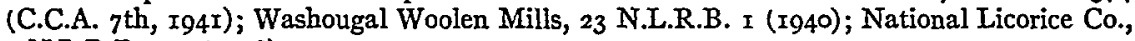
7 N.L.R.B. 537 (1938).

I9 Any necessity for making such a distinction disappeared "as soon as the authority of the certified agent was made expressly paramount. It then became the natural understanding that those 'grievances' which could be 'adjusted' comprised all disputes which could be covered in a collective agreement; and that meant every kind of dispute, for all disputes can be covered by a collective agreement." I73 F. 2d 764, 769 (C.A. 2d, r949). 
ity" which he did not before possess. This paramount authority was said to stem from the express provision that separate grievance adjustments must not conflict with an existing collective agreement. It consists, said the court, of the representative's power either to provide for future disputes in the collective contract or 'to take over the 'adjustment' of any 'grievance,' whether it has been already 'adjusted,' or is in process of 'adjustment,' and by including it in a collective agreement with the employer, finally to dispose of it." "20 Such authority is said to eliminate the need for any distinction between "grievances" and matters appropriate to collective bargaining, for until a collective agreement is made there is nothing with which grievance adjustments can conflict, and once such an agreement is in effect, any conflict on matters covered by that agreement is resolved in favor of the agreement. Thus the court interprets the Act as investing the certified representative with no more than the authority to contract for all the employees in the unit, for "until he chooses to contract, and insofar as his contract leaves open any point in dispute, present or future, the employees retain their common-law right to bargain for themselves, singly or collectively."2x

It is revealing to compare the legislative history of the amendment of the Section 9 (a) proviso with Judge Hand's conclusion that it has invested the bargaining representative with paramount authority which he did not before possess. The Senate Report indicates that Congress intended not to increase the rights of the bargaining representative, but rather to give concrete expression to a limitation upon that right. The words added by the amendment secured the right of employees separately to adjust grievances with their employer, a right which was to exist independently of any right possessed by the bargaining representative. ${ }^{22}$ An exception was made to this right, however, where the proposed adjustment would conflict with an existing collective agreement. According to Judge Hand, it is this exception which has invested the representative with paramount authority, yet it is an exception which, while not expressed, was read into the Wagner Act even by the courts most anxious to preserve the

${ }^{20} \mathrm{Ibid}$. This description of the bargaining representative's powers, while not necessary to the holding of the case, leaves unanswered a number of questions as to how far Judge Hand would go in permitting interference with the right of separate grievance adjustment. What would be the effect of a contractual provision requiring negotiation with the representative with respect to "all disputes arising out of the employment relationship"? How does one "adjust" a grievance which has already been "adjusted"? Does the representative's power extend to settlements already made or does it only permit him to cancel settlements which set employment conditions for the future? And what of an adjustment made or proposed which is not inconsistent with the existing contract?

${ }^{21}$ I73 F. 2d 764, 769 (C.A. 2d, r 949 ).

22 Senate Report 105, 8oth Cong. Ist Sess., at 24 (1947). The Board is criticized for not having "given full effect" in the past to the proviso and the amendment is said to make it "clear that the employee's right to present grievances exists independently of the rights of the bargaining representative." See also House Report 245 on H.R. 3020, 8oth Cong. 2d Sess. (1947). 
independent right of separate grievance adjustment. ${ }^{23}$ Since the distinction between grievances and other disputes was considered fundamental while the exception was implicit in the old Act, it is strange indeed to conclude that the necessity for the distinction has been ended by making the exception express.

Moreover, it is by no means clear that the bargaining representative has so much authority as Judge Hand seems to think. To say that the representative can completely bar separate adjustment of personal disputes arising in the future would seem to contradict the terms and spirit of the proviso. ${ }^{24}$ Doubts as to his authority to bar individual adjustments of existing personal claims are raised by a Supreme Court interpretation of the-Railway Labor Act. ${ }^{25}$ As to his power to "cancel" individual adjustments, it is true that under the old Act he could cancel employee contracts concerning future wages, hours, and general conditions of employment, ${ }^{26}$ but in the Local I250 case this power probably could not be exercised by the bargaining representative. Thus if Local I25 had been able to "adjust" its "grievance" by having the fifty-one members reinstated, it might be an unfair labor practice for the representative to attempt to "cancel" that adjustment by having them discharged for any reason other than their failure to tender the uniform dues and initiation fee.7

Even more important is Judge Hand's interpretation of the effect of the Act on all disputes arising before a collective agreement is made and on all disputes not provided for in an existing agreement. He asserts that with respect to such disputes mere certification does not create an obligation on the employer to bargain exclusively with the statutory representative, nor does it end his commonlaw right to contract with individual employees. Such an interpretation is a virtual nullification of the most important provisions of the Act. The statutory right of exclusive representation is of limited value in respect to any question already provided for in an existing contract; $; 2$ it is of the utmost importance, however, in obtaining recognition for negotiating that contract or for adjusting

${ }^{23}$ It should be remembered that the representative's "paramount authority" as seen by the Courts of Appeals for the Fifth and Ninth Circuits was derived, not from the implicit requirement of consistency with the existing agreement, but rather from the provisions of Sections $8(5)$ and $9(a)$.

${ }^{24}$ See Olverson, Collective Bargaining and the Taft-Hartley Labor Act, 33 Va. L. Rev. 549, 57 (I947). The Court of Appeals for the Ninth Circuit had earlier suggested, by way of dictum, that the rights reserved by the proviso could not be nullified by incorporating every possible dispute into the collective agreement. NLRB v. North American Aviation, I36 F. $2 \mathrm{~d} 898,899$ (C.C.A. 9 th, I943). In this respect, Judge Hand's interpretation is similar to the Board's position in U.S. Automatic Corp., 57 N.L.R.B. I24 (I944).

${ }^{25}$ Elgin, Joliet \& Eastern Ry. Co. v. Burley, 325 U.S. 7 II (I945), holding that the bargaining representative did not have the authority to adjust individual grievances.

${ }^{26} \mathrm{~J}$. I. Case Co. v. NLRB, 32 I U.S. 332 (1944).

${ }^{27}$ Section $8(\mathrm{~b})(2)$ of the amended Act makes it an unfair labor practice for a union to cause an employer to discriminate against an employee with respect to whom union membership has been denied for any reason other than his failure to tender the periodic dues and uniform initiation fee.

${ }^{28}$ The same right would presumably be available to any union which had obtained such a contract with the employer without the aid of the statute. 
disputes for which provision has not been made. ${ }^{29}$ Sections $8(5)$ and 9 (a) of the Act, which impose on employers the duty to bargain exclusively with the certified representative on matters affecting the basic employment relationship, cannot be made to depend on the existence or nonexistence of a collective contract if the principle of collective bargaining is to be preserved. In thus limiting the application of those sections, Judge Hand has threatened the principles which both the Wagner and Taft-Hartley Acts were designed to promote. The congressional purpose of encouraging collective bargaining and promoting stable employment relationships is not achieved by his interpretation. ${ }^{30}$

The Local $125^{\circ}$ case also decided the separate question of whether a rival union might represent a group of employees in the adjustment of grievances. While nothing in the original Act expressly prohibited such representation, it had been held that while an employee "may ask an experienced friend to assist him," he "cannot present grievances through any union except the [bargaining] representative." $3 x$ That holding had been based partly on the fear that permitting a rival union to negotiate with the employer would result in the kind of inter-union strife which the Act was designed to prevent. Importance was also attached to the fact that, in adopting the proviso to Section 9(a), Congress considered and rejected the addition of the words "through representatives of their own choosing." "3a

Judge Hand has held that any necessity for barring grievance adjustments by rival unions was ended when the proviso to Section 9 (a) was amended. By ending the possibility of conflict between grievance adjustments and the collective agreement, that amendment is said to have ended the threat of possible conflict between rival unions. ${ }^{33}$ Grievance negotiations, as the court points out,

29 "[T]he important principle is that the union has the power to exclude all changes unless it is given the opportunity to bargain in respect thereto. Only if the statutory representative is accorded by law the power to preempt the field as against all individuals or groups . . . can collective bargaining be protected." Weyand, op. cit. supra note 6 , at 573 .

${ }^{30}$ Section I of both the original and amended Acts declares it to be the policy of the United States to encourage "the practice and procedure of collective bargaining" and to protect "the exercise by workers of full freedom of association, self-organization, and designation of representatives of their own choosing, for the purpose of negotiating the terms and conditions of their employment or other mutual aid or protection." See also 34 Corn. L. Rev. 655 (x949), noting the Local 1250 case, at 658 .

${ }^{3 x}$ Hughes Tool Co. v. NLRB, I47 F. 2d 69, 73 (C.C.A. 5th, I945); cf. Gulf State Utilities Co., 42 N.L.R.B. 988 (r942).

${ }^{32}$ The use of this phrase in the Railway Labor Act led the courts to conclude that a rival union could represent employees in grievance session. Elgin, Joliet \& Eastern Ry. Co. v. Burley, 325 U.S. 7 II (1945). See also 40 Ops. Att'y Gen. 494 (1946).

33 This argument becomes unconvincing when it is remembered that the Court of Appeals for the Fifth Circuit, while barring the rival union, had also made conflict between grievance adjustments and the collective contract virtually impossible by requiring negotiations with the representative where the adjustment involved an interpretation of that contract. The same thing can be said of the court's further argument that the necessity of barring rival unions disappeared when the representative was given the opportunity to be present at any grievance adjustment, for this right was also implied from the old Act. Hughes Tool Co. v. NLRB, I47 F. $2 d 69$ (C.C.A. 5th, I945). 
require a degree of proficiency and training not possessed by the ordinary employee. It was therefore held to be inconceivable that Congress, having given employees the express right to adjust grievances without the intervention of the bargaining representative, would deny them the best and most experienced representation in that adjustment.

Exclusive representation in the handling of grievances has long been one of the most valued rights of unions, for not only is the adjustment of any grievance likely to have some effect on the working unit as a whole, ${ }^{34}$ but it is also likely to produce the kind of immediate rewards for the aggrieved employee which will win his gratitude and future support. It was therefore natural that even under the limited interpretation of grievance adjustment, a certified union might strongly object to participation by its greatest rival in such negotiations. But under the rationale of the Court of Appeals for the Second Circuit, where disputes going to the root of the employment relationship have become proper subject matter for such grievance adjustment, it would seem that the objections of the certified union would be doubly strong. To permit a rival union to negotiate with respect to wages, hours, and general conditions of employment is to permit the kind of union rivalry which is so destructive to sound industrial relations. Competition between unions for the support of employees is necessary to representative unionism, but it has no place at the bargining table.

As for the employer, it might be argued that the Local 1250 decision will be a benefit because of his new opportunity to "play off" one union against another. But at the same time he will lose a large measure of the protection against damaging strikes by minority unions which he might have had by virtue of Section 8(b) (4) (c) of the Act. ${ }^{35}$ In a like manner, he will also lose the stability and security which could have been offered by the certified union under the Hughes Tool Co. decision. ${ }^{36}$

\section{FREE SPEECH vS. THE FAIR TRIAL IN THE ENGLISH AND AMERICAN LAW OF CONTEMPT BY PUBLICATION}

The contrast is striking between the English law of contempt by publication, ${ }^{\mathbf{x}}$ which is both clear and consistently enforced, and the heterogeneous law and

${ }^{34}$ Even the adjustment of the most personal grievance is likely to set a precedent for the established working conditions of the future. See Settling Plant Grievances, Div. of Labor Standards, Bulletin No. 60, at 37-38 (U.S. Dept. of Labor, 1943).

${ }_{35}$ See 63 Harv. L. Rev. 36 r, 362 (1949), noting the Local 1250 case.

${ }^{36} \mathrm{It}$ is well recognized that the employer usually gains, by virtue of collective bargaining, certain stability of wages, security against work stoppages, and the promise of a constant supply of trained workers. See Williamson and Farris, Trends in Collective Bargaining 215-I7 (x945).

I The term "publication" is used herein in the broadest sense to include not only newspaper articles but also radio broadcasts, Baltimore Radio Show, Inc. v. State, 67 A. 2 d 497 (I949), cert. den. 70 S. Ct. 252 (I950), conversation, Robinson v. City Court, I85 P. 2 d 256 (I947), posted notices, Butler v. Butler, ${ }_{3}$ P.D. 73 (1888), pamphlets, State v. Shumaker, 200 Ind. $623,{ }_{57}$ N.E. $769, x_{2}$ N.E. 44 I, I6 3 N.E. 272 (I927), and theatrical exhibits, Rex v.Williams and Romney, 2 L.J. (O.S.) 30 (K.B., I823). 